7. Reprod. Fert. (1966) 11, 451-453

BRIEF COMMUNICATION

\title{
EFFECT OF AMYGDALOID LESIONS ON OESTROUS BEHAVIOUR IN THE DEERMOUSE
}

\author{
B. E. ELEFTHERIOU AND A. J. ZOLOVICK \\ Department of Zoology, Kansas State University, Manhattan, Kansas, U.S.A.
}

(Received 22nd October 1965)

\begin{abstract}
Summary. Lesions were placed bilaterally in the medial and basolateral amygdaloid nuclei of adult female deermice $(P . \mathrm{m}$. bairdii) by means of a Radio Frequency Lesion Maker with a current of $20 \mu \mathrm{A} / 30$ sec. It was found that females with lesions in the basolateral amygdaloid nucleus exhibited normal cyclic vaginal smears and mating activities. However, $30 \%$ of the females exhibited hypersexuality as evaluated by excessive mating and reception of the male during dioestrus. Females with lesions in the medial amygdaloid nucleus exhibited normal oestrous cyclic activity, but did not mate during the entire 30-day period of the experiment. It is concluded that the medial amygdaloid nucleus may be involved in the nervous mechanism of normal mating.
\end{abstract}

Sexual behaviour in males of several species has been altered by amygdaloid lesions. Many investigators have found that a few weeks after bilateral ablation of the amygdala males become hypersexual (Brady, Schreiner, Geller \& Kling, 1954; Fuller, Rosvold \& Pribram, 1957; Green, Clemente \& DeGroot, 1957; Masserman, Levitt, McAvoy, Kling \& Pechtel, 1958; Wood, 1958; Anand, Malhotra, Singh \& Dua, 1959; Kling, Orbach, Schwartz \& Towne, 1960; Orbach, Milner \& Rasmussen, 1960). Several other authors, however, have found that amygdalectomy causes a decrease in sexual behaviour (Thompson \& Walker, 1950, 1951; Walker, Thompson \& McQueen, 1953; Kling \& Schwartz, 1961). The major effect on female behaviour following amygdaloid lesions is the disruption of maternal behaviour. In instances where an amygdalectomized monkey has given birth, the infant has a limited chance of survival (Walker $e t$ al., 1953; Masserman et al., 1958).

This work was conducted in order to investigate the effects of bilateral amygdaloid lesions on the oestrous cycle and mating behaviour in a wild species, the deermouse (Peromyscus maniculatus bairdii).

Adult female deermice (P. m. bairdii) with a body weight of 17 to $19 \mathrm{~g}$ were anaesthetized with Nembutal, placed in a standard rat stereotaxic instrument and lesioned bilaterally in either the basolateral or ventromedial amygdaloid nuclei. A Radio Frequency Lesion Maker (Grass Instruments Inc.) was used discharging $20 \mu \mathrm{A}$ of current for $30 \mathrm{sec}$, and producing lesions with a maximum diameter of $0.4 \mathrm{~mm}$. The electrodes used for placing the lesions were made of 
30 gauge platinum wire insulated to $0.5 \mathrm{~mm}$ of the tip with a polyvinyl plastic coating. The locations of the lesions were based on a stereotaxic atlas prepared in our laboratory for this animal (Eleftheriou \& Zolovick, 1966).

All females were housed in individual new or de-scented transparent plastic cages and given unlimited water and standard laboratory rat chow throughout the experiment. After a 2-day rest period, a fertile stud male was placed in the cage with the female, and the oestrous cycle followed by daily vaginal smears. If more than twenty spermatozoa per microscope field (objective $\times 10$, ocular $\times 10$ ) were found in the wet vaginal smear, the male was removed and the female left alone for 10 to 15 days at which time she was killed. Location of the lesions was confirmed by histological examination.

Results indicate that bilateral lesions of the basolateral amygdaloid nucleus did not disrupt the oestrous cycle (Table 1). However, mating behaviour was altered in that $30 \%$ of these females mated and received the male while in dioestrus. This finding may indicate a hypersexual condition and if so, it would

\section{TABLE 1}

SUMMARY OF DATA ON OESTROUS GYCLIC AND MATING BEHAVIOUR IN INTAGT NORMAL AND AMYGDALECTOMIZED FEMALE DEERMICE ( $P$. $m$. bairdii)

\begin{tabular}{l|c|c|c|c|c}
\hline \multicolumn{1}{c|}{ Treatment } & $\begin{array}{c}\text { No. of } \\
\text { animals }\end{array}$ & $\begin{array}{c}\text { Oestrous } \\
\text { conditions }\end{array}$ & $\begin{array}{c}\text { Oestrous } \\
\text { behaviour }\end{array}$ & \multicolumn{2}{|c}{ Per cent mating } \\
\cline { 4 - 5 } & 25 & First oestrus & Second oestrus \\
\hline $\begin{array}{l}\text { Intact, normal } \\
\begin{array}{l}\text { Lesioned: } \\
\text { ventromedial }\end{array}\end{array}$ & 20 & Cyclic & Mating & 92 & 8 \\
$\begin{array}{l}\text { amygdaloid } \\
\text { nuclei }\end{array}$ & 24 & Cyclic & Mating & 62 & 38 \\
$\begin{array}{l}\text { Basolateral } \\
\text { amygdaloid } \\
\text { nuclei }\end{array}$ & & & 0 & 0 \\
\hline
\end{tabular}

be the first instance in which such behaviour has been recorded in females of any species, although such lesions do produce hypersexuality in males (Brady et al., 1954; Fuller et al., 1957; Green et al., 1957; Masserman et al., 1958; Wood, 1958; Anand et al., 1959; Kling et al., 1960; Orbach et al., 1960). No precocious ovarian stimulation following amygdaloid lesions was noted as has been reported for the rat by Elwers \& Critchlow (1960).

Lesions in the medial amygdaloid nuclei did not alter oestrous cyclic activity, but females lesioned in this area were not receptive to the male. A possible explanation for this type of behaviour may be that animals lesioned in this area may have become hyperemotional although during the experiment this reaction was not measured. It is known, however, that the amygdaloid complex mediates such behavioural patterns as fear, anger, rage and alerting reactions. An alternative hypothesis may be that this area is part of a 'psychic heat' centre the destruction of which rendered the female non-receptive to the male. The causative mechanism for this behaviour, as well as plasma and pituitary levels of oestrogens and gonadotrophins, are now being investigated. 
Contribution No. 361 Department of Zoology, Kansas Agricultural Experiment Station, Manhattan. Supported in part by grant No. HD-00013 from National Institute of Child Health and Human Development, National Institutes of Health, Bethesda, Maryland.

\section{REFERENGES}

Anand, B. K., Malhotra, C. L., Singh, B. \& Dua, S. (1959) Cerebellar projections to limbic system. 7. Neurophysiol. 22, 451.

Brady, J. V., Schreiner, L., Geller, I. \& Kling, A. (1954) Subcortical mechanisms in emotional behavior: The effect of rhinencephalic injury upon the acquisition and retention of a conditoned avoidance response in cats. F. comp. physiol. Psychol. 47, 179.

Eleftheriou, B. E. \& Zolovick, A. J. (1966) An atlas of the forebrain of the deermouse in stereotaxic coordinates. F. comp. Neurol. (In press).

Elwers, M. \& CRItchlow, V. (1960) Precocious ovarian stimulation following hypothalamic and amygdaloid lesions in rats. Amer. F. Physiol. 198, 381.

Fuller, J. L., Rosvold, H. E. \& Pribram, K. H. (1957) The effect on affective and cognitive behavior in the dog of lesions of the pyriform-amygdala-hippocampal complex. F. comp. physiol. Psychol. $50,89$.

Green, J. D., Clemente, C. D. \& DeGroot, J. (1957) Rhinencephalic lesions and behaviour in cats. 7. comp. Neurol. 108, 505.

Kling, A., Orbach, J., Schwartz, N. B. \& Towne, J. C. (1960) Injury to the limbic system and associated structures in cats. Archs gen. Psychiat. 3, 391.

Kling, A. \& Schwartz, N. B. (1961) Effects of amygdalectomy on sexual behaviour and reproductive capacity in the male rat. Fedn Proc. Fedn Am. Socs exp. Biol. 20, 335.

Masserman, J. H., Levitt, M., McAvoy, T., Kling, A. \& Pechtel, C. (1958) The amygdalae and behaviour. Am. F. Psychiat. 115, 14.

Orbach, J., Milner, B. \& Rasmussen, T. (1960) Learning and retention in monkeys after amygdalahippocampus resection. Arch. Neurol. 3, 230.

Thompson, A. F. \& WALker, A. E. (1950) Behavioral alterations following lesions of the medial surface of the temporal lobe. Folia psychiat. neurol. neurochir. neerl. 53, 444.

Thompson, A. F. \& WALKER, A. E. (1951) Behaviors niterations following lesions of the medial surface of the temporal lobe. Archs Neurol Psychiat. 63, 251.

WAlker, A. E., Thompson, A. F. \& McQueEn, J. D. (1953) Behavior and the temporal rhinencephalon in the monkey. Fohns Hopkins Hosp. Bull. 93, 65,

Wood, C. D. (1958) Behavioral changes following discrete lesions of temporal lobe structures. Neurology, 8, 215. 